\title{
PROS AND CONS OF DISTANCE LEARNING FOR MEDICAL STUDENTS UNDER QUARANTINE CONDITIONS
}

\author{
І. А. Бандас, Л. М. Палиця, О. А. Скобеєва \\ Тернопільський національний медичний університет імені І. Я. Горбачевського МОЗ Украӥни \\ ПЛЮСИ І МІНУСИ ДИСТАНЦЙНОГО НАВЧАННЯ ДЛЯ СТУДЕНТІВ- \\ МЕДИКІВ ЗА КАРАНТИННИХ УМОВ
}

\begin{abstract}
The pandemic of coronavirus disease (COVID-19) had a significant impact on the social life of medical students, which contributed to the active use of distance learning technologies. Distance learning - "a synthetic, integrated humanistic form of learning based on the use of a wide range of traditional and new information technologies and their technical means, which are used to present educational material, its independent study, dialogue between a lecturer and a student, and the learning process, in the general case, is uncritical to their location in space and time, as well as to a specific educational institution. Existing technologies of distance learning through the use of modern digital platforms, high-quality content of educational web resources, the introduction of an effective knowledge quality control system give us the opportunity to adapt to new realities of the educational process and ensure consistently high quality of postgraduate medical education.

This article presents a system of scientific ideas, mechanisms, advantages and disadvantages of distance (remote) learning in medical institution.
\end{abstract}

Key words: pandemic; distance learning; form; integration; analysis; education.

Анотація. Пандемія коронавірусної хвороби (COVID-19) внесла істотний вплив на соціальне життя студентів-медиків, це посприяло активному застосуванню навчальних дистанційних технологій. Дистанційне навчання - це синтетична, інтегральна гуманістична форма навчання, що базується на використанні широкого спектра традиційних та нових інформаційних технологій і їх технічних засобів, які застосовуються для доставки навчального матеріалу, його самостійного вивчення, діалогового обміну між викладачем і студентами, причому процес навчання в загальному випадку некритичний до їхнього розташування в просторі і в часі, а також до конкретного освітнього закладу. Існуючі на даний момент технології дистанційного навчання за допомогою використання сучасних цифрових платформ, якісного контентного наповнення освітніх веб-ресурсів, запровадження ефективної системи контролю якості отриманих знань дають нам можливість адаптуватися до нових реалій освітнього процесу та забезпечити незмінно високу якість післядипломної медичної освіти.

У даній статті представлено систему наукових уявлень, механізми, плюси та мінуси дистанційної (віддаленої) освіти у медичному ЗВО.

Ключові слова: пандемія; дистанційне навчання; форма; інтеграція; аналіз; освіта.

Introduction. Distance learning is nowadays one of the most promising and relevant forms of learning, which provides interaction between students and lecturers, but requires special technical equipment and appropriate skills in its use [6]. Distance learning is one of the revolutionary approaches to student feedback from lecturers, which provides the necessary learning materials, knowledge and skills [10]. The introduction of distance learning for medical students as part of the general educational process is a promising area of medical education [1].

Distance learning - a new "phenomenon" for Ukraine, as to date it has been used quite rarely in the educational process. However, in many countries around the world this form of education is not new and is widely used. In in particular, 2,5 million pupils and students study at home independently in the USA and their number is growing every year.

(C) I. A. Bandas, L. M. Palytsia, O. A. Skobeieva 
Distance learning is the most flexible and accessible. In addition, distance learning meets the requirements of the new educational paradigm of the information society, namely: support for open, personality-oriented and lifelong learning; implementation of mass education for all categories of the population, regardless of their place of residence; diversification and improvement of professional training in higher education institutions through meeting the diverse needs of students from different social and demographic groups [7, 9].

Distance learning is especially important now, as much of the world is quarantined and decides how to stop the further spread of COVID-19.

In today's reality, traditional medical education has gone beyond the usual routine of the COVID-19 pandemic worldwide [9]. According to the Director-General of UNESCO Audrey Azulai, more than 1,5 billion young people in 165 countries have lost the opportunity to attend educational institutions. To maintain the continuity of medical education during quarantine restrictions, universities were forced to reorganize the educational process by creating online classes $[6,7]$. With the announcement of the quarantine, the study is remote in I. Horbachevsky Ternopil National Medical University of the Ministry of Public Health of Ukraine (TNMU), as well as in all educational institutions of Ukraine and the world. The introduction of distance learning as part of the educational process is a promising area of medical education [1].

Medical educators need to stay abreast of new technologies and incorporate them into teaching during and after the pandemic. So better preparation of our teaching teams, our students, and the system stands out as an essential alternative during and posterior to the pandemic. The literature suggests that key barriers which affect the development and implementation of online learning in medical education include time constraints, poor technical skills, inadequate infrastructure, absence of institutional strategies and support, and negative attitudes [7].

With the increasing use of technology in education, online learning has become a common teaching method. Compared to offline learning, online learning has advantages to enhance undergraduates' knowledge and skills; therefore, it can be considered as a potential method in undergraduate medical education [6]. During the COVID-19 pandemic, this has become an obligation for medical schools around the world and it is time for newbie institutions to align with this new requirement in terms of online education.

The aim - to evaluate the advantages and disadvantages of distance learning in the study of the subject
"Biological and Bioorganic Chemistry" for medical students in I. Ya. Horbachevsky Ternopil National Medical University of the Ministry of Public Health of Ukraine.

Methods. Analysis, synthesis, modeling.

Results. The Department of Biochemistry conducts classes and lectures on biological and bioorganic chemistry for students of the Faculty of Medicine, the Faculty of Pharmacy and the Faculty of Dentistry, as well as for part-time students and students of the Institute of Nursing. Biochemistry plays an important role in mastering the subjects studied by students of senior courses and has close integration links with all subjects without exception [1].

The study of biological and bioorganic chemistry lays the foundations for students to master molecular biology, genetics, physiology, pathology, general and molecular pharmacology, toxicology and propaedeutics of medical subjects. This relationship involves and provides the formation of skills to apply knowledge of the dynamics of biochemical processes in further education and professional activities.

The order of the Ministry of Education and Science of Ukraine dated April 25, 2013 No. 466 “On Approval of the Regulations on Distance Learning” states that "the purpose of distance learning is to provide educational services through the use of modern information and communication technologies at certain educational or educational and qualification levels in accordance with state standards of education" [11].

There are several types of distance learning courses in Ukrainian universities: face-to-face online practice classes, seminars, multimedia presentations, video materials, video lectures and consultations, where students can ask questions and make up missed classes. This allows to study anywhere and at an individual pace.

According to the order of the rector of TNMU № 238 from 22.06.2020 - practical classes and lectures for university students were transferred into extracurricular mode with the help of implemented interactive teaching methods, in particular the service Microsoft Teams. The advantages of using this program are ease of use, a variety of options and the ability to use interactive teaching methods. Also, in terms of quarantine the maximum has been the use of e-learning system Moodle, which has been introduced into the educational process of TNMU named after I. Ya. Horbachevsky of the Ministry of Public Health of Ukraine since the beginning of 2006 [7] and is actively used by students and lecturers. This platform contains text and video materials in preparation for practical classes, presentations and content of lectures, as well as test tasks for 
student self-control. All the above allowed not to stop the educational process and online assessment of student performance during the quarantine period from March 2020 to June 2021 and to ensure their continuous professional development.

The main task of biological chemistry as a fundamental subject - to provide a scientific approach and lay new theoretical foundations for clinical thinking of future medical students, dentists and pharmacists. Bioorganic and biological chemistry as a scientific subject in medical education is designed to create a basis, a foundation for further study of clinical subjects. Along with this, biochemistry and molecular biology are the areas of biomedical science that are most actively developing and provide widespread implementation of biochemical, biotechnological and molecular methods in the diagnosis and treatment of diseases [9]. Therefore, modern medical professionals should have deep knowledge of biochemical processes and use them in solving professional issues.

The main difficulty, faced by the lecturer when working with a group, is the difference in the initial level of preparation of the student, which can vary widely. The short period of study of the subject and the high saturation of each lesson complicate the process of adaptation of students with a low initial level of knowledge, which leads to a decrease in his/her motivation to learn. The course of biological chemistry for medical students, dentists, pharmacists is quite extensive and difficult to understand. Therefore, the clarity and systematization of the material in the form of diagrams, drawings, tables facilitate the perception and memorization of difficult to understand material. On the website of the department students can find theoretical material, which is placed both in the form of text materials, as well as in the form of video content and presentations from all sections of the subject. During the study of the subject students learn to explain the features of the structure and transformations in the body of bioorganic compounds; to analyze the conformity of the structure of bioorganic compounds to the physiological functions they perform in the human body; to interpret the relationship between the structure of bioorganic compounds, the peculiarities of their metabolism and physiological functions in the human body; to explain the biochemical and molecular basis of physiological functions of cells, organs and systems of the human body; to interpret the main biochemical mechanisms of pathological processes in the human body and the principles of their correction; to characterize the peculiarities of the physiological state of the organism and the development of pathological processes on the basis of laboratory tests; to interpret the features of the structure and transformations in the body of bioorganic compounds, which are based on their use in medicine as drugs; to interpret the methodology of conducting and to perform certain biochemical research methods that underlie the laboratory diagnosis of pathological conditions [5, 6]. Perfect mastering of the necessary basis of knowledge, skills and abilities in biological chemistry lays the foundation for further study of professional subjects. Distance learning today helps students to develop such qualities as independence, mobility and responsibility, develops self-education skills, which is highly valued in the labour market.

Practical classes in biological chemistry lasting an hour and a half were held according to the department schedule in video mode. Each class consisted of 3 parts: seminar discussion, analysis of situational tasks and questions of the license exam "Krok-1" and test control. The main strategy of such interactive learning is a student as an active participant in the educational process. During the class, students had the opportunity to chat in the Microsoft Teams with lecturers, who provided advice on practical classes, answered questions, helped to solve problems. Also on this platform, students had the opportunity to send photos of completed tasks for testing by lecturers. Knowledge control at the end of each class was performed using 24 test questions, which were solved online in the Moodle system. Final grades for practical classes were displayed in the electronic journal of the automated control system of TNMU.

Also during the study in terms of quarantine was introduced the remote make up of negative grades by students and the missed practical classes according to the schedule.

The independence of the student from the territorial location of the higher education institution is an important advantage of distance learning, because a significant part of TNMU students are citizens of other countries. However, from the lecturer's experience, an important number of shortcomings can be identified, in particular: distraction of attention of a student and a lecturer, quality of Internet connection, anxiety, constant access of students to sources of information, lack of practical classes, constant control, personal control and personal communication. In addition, students do not always have the self-discipline, awareness and independence that are necessary for distance learning [6, 10]. It also happens that the tasks offered to the student, to test knowledge, are performed by the friends. The 
main difficulty - to force oneself to study. The disadvantages include the fact that students do not have wide access to the database of modern educational and scientific literature provided by the university. There is also no direct communication between students.

Conclusions and Prospects for Research. Given the abovementioned, in order to increase the effectiveness of distance learning, it is important to enrich its content with the achievements of visual studies, visual culture, video lessons, virtual patient simulator, which can help better understand the material [4]. However, the interaction of a student and a patient, the development of clinical thinking, clinical skills is a necessary component of all educational programs of medical universities, and all the proposed methods do not replace real contact with the patient $[3,5]$. The effectiveness of the distance learning process depends not only on the use of modern digital technologies, but also on the awareness of the need for a creative approach to work, establishing interaction between students and teachers. Distance learning in medical universities requires a careful analysis of both the evaluation of the effectiveness of learning and the perception of the role of e-learning by medical students. Pedagogical approaches to teaching constantly require the search for new tools that can bring an element of novelty to the educational process, while increasing the interest of students, especially during the quarantine period (COVID-19) $[2,8,9]$.
Regardless of reported benefits, medical students preferred the blended approach in teaching as distance learning represented a major challenge to acquire adequate clinical medical skills. Satisfaction in distance learning is strongly linked to students' prior experience in distance learning as well as instructors' experiences and interactions. Technical and infrastructural resources reported as a major challenge for implementing distance learning, so understanding technological, financial, institutional, educators, and student barriers are essential for the successful implementation of distance learning in medical education.

Absence of direct contact, $100 \%$ social distance, no infectious risks - all these are the advantages of distance learning during the epidemic. But first of all, it is impossible to fully ensure the need to learn the practical skills of medical students in terms of distance learning.

Also, it is imperative to take into consideration the difficulties and challenges of a transition to online education in medical studies. It requires a balance between learning, development of skills, and some clinical and practical skills. Furhter, it is important not to change the habits of the students and teachers who do not master the use of software and teaching platforms.

Online education lacks specific quantitative standards to measure the quality of the teaching process. This affects the learning effectiveness of medical students and needs to be addressed further.

\section{List of literature}

1. Гонський Я. І. Біохімія людини : підручник / Я. І. Гонський, Т. П. Максимчук, М. І. Калинський. Тернопіль : Укрмедкнига, 2002. - С. 7-14.

2. Даниленко Г. М. Проблеми формування освітнього середовища для студентів-медиків / Г. М. Даниленко // Проблеми сучасної освіти : зб. наук.-метод. праць. - Х. : ХНУ ім. В. Н. Каразіна, 2019. - С. 29-38.

3. Дистанційне навчання - вимушений захід чи вимога часу (на прикладі Тернопільського національного медичного університету імені І. Я. Горбачевського МОЗ України)? / М. М. Корда, А. Г. Шульгай, А. І. Машталір, А. В. Чорномидз // Медична освіта. - 2021. - № 2. C. $35-40$.

4. Дівнич Т. Я. Дистанційна форма навчання у вищих навчальних закладах як одна із технологій організації навчального процесу / Т. Я. Дівнич // Медична освіта. 2015. - № 3. - С. 66-69.

5. Маража I. О. Роль педагогіки в клінічній практиці лікаря / I. О. Маража, І. В. Жулкевич // Медична освіта. - 2021. - № 2. - С. 94-99.

6. Переваги і недоліки дистанційного навчання в цілому та при вивченні дисципліни «Гістологія, ци-

тологія, ембріологія» / І. Б. Гетманюк, С. Б. Крамар, 3. М. Небесна, О. Я. Шутурма // Медична освіта. 2020. - № 4. - С. 16-19.

7. Про затвердження Положення про дистанційне навчання [Електронний ресурс]. - Режим доступу : https:// osvita.ua/legislation/ Dist_osv/2999.

8. Штихно Л.В.Дистанційне навчання як перспективний напрям розвитку освіти / Л. В. Штихно // Молодий вчений. - 2016. - № 6. - С. 489-492.

9. Ястремська С. О. Застосування системи MOODLE в дистанційному навчанні магістрів сестринської справи / С. О. Ястремська // Вісник Львівського державного університету безпеки життєдіяльності. - 2017. - № 16. C. $186-190$.

10. Arkorful V. The role of e-learning, advantages and disadvantages of its adoption in higher education / V. Arkorful, N. Abaidoo // Int. J. Educ. Res. - 2015. - Vol. 12 (1). P. 29-42.

11. Baqir S. M. Online medical education and examinations during COVID-19: perspectives of a teaching associate / S. M. Baqir, F. Mustansir // J. Coll. Physicians Surg. Pak. 2015. - Vol. 31 (1). - P. 16-18. 


\section{References}

1. Gonsky, J.I, Maksymchuk, T.P, \& Kalinsky, M.I. (2002). Biohimiia liudyny [Human biochemistry]. Ternopil: Ukrmedknyha [in Ukrainian].

2. Danylenko, H.M. (2019). Problemy formuvannia osvitnoho seredovyshcha dlia studentiv-medykiv [Problems of formation of educational environment for medical students]. Problemy suchasnoi osvity: zbirnyk naukovo-metodychnykh prats - Problems of modern education: a collection of scientific and methodical works. (pp. 29-38). Khakkiv: KhNU im. V. N. Karazina [in Ukrainian].

3. Korda, M.M., Chornomydz, A.V., Shulhai, A.H., \& Mashtalir, A.I. (2021). Osoblyvosti funktsionuvannia systemy vnutrishnoho zabezpechennia yakosti vyshchoi osvity v Ternopilskomu natsionalnomu medychnomu universyteti imeni I. Ya. Horbachevskoho MOZ Ukrainy [Features of functioning of the system of internal quality assurance of higher education at I. Horbachevsky Ternopil National Medical University Ministry of Health of Ukraine]. Medychna osvita - Medical Education, 2, 35-40 [in Ukrainian].

4. Divnych, T.Ya. (2015). Dystansiina forma navchannia u navchalnyh zakladah yak odna iz form tehnologiia organizasii navchalnogo prosec una e technologiae institutionis processus edificationis [Distance form of education in higher educational institutions as one of the technologies of organization of educational process]. Medychna osvita - Medical Education, 3, 66-69 [in Ukrainian].

5. Marazha, I.O., \& Zhulkevych, I.V. (2021). Rol pedahohiky v klinichnii praktytsi likaria [The role of pedagogy in the clinical practice of the doctor]. Medychna osvita - Medical Education, 2, 94-99 [in Ukrainian].

E-mail address for correspondence: palicalm@tdmu.edu.ua
6. Hetmaniuk, I.B., Kramar, S.B., Nebesna, Z.M., \& Shuturma, O.Ya. (2020). Perevahy i nedoliky dystantsiinoho navchannia $\mathrm{v}$ tsilomu ta pry vyvchenni dystsypliny «Histolohiia, tsytolohiia, embriolohiia» [Advantages and disadvantages of distance learning in general and in the study of the discipline "Histology, cytology, embryology"]. Medychna osvita - Medical Education, 4, 16-19 [in Ukrainian].

7. Pro zatverdzhennia Polozhennia pro dystantsiine navchannia [Regulations on distance learning]. Retrieved from: https://osvita.ua/legislation/Dist_osv/2999 [in Ukrainian].

8. Shtykhno, L.V. (2016). Dystantsiine navchannia yak perspektyvnyi napriam rozvytku suchasnoi osvity [Distance learning as a promising area of modern education]. Molodyi vchenyi - Young Scientist, 6 (33), 489-495 [in Ukrainian].

9. Yastremska, S.O. (2017). Zastosuvannia systemy MOODLE v dystantsiinomu navchanni mahistriv sestrynskoi spravy [Application of the MOODLE system in distance learning of masters of nursing]. Visnyk Lvivskoho derzhavnoho universytetu bezpeky zhyttiediialnosti - Bulletin of Lviv State University of Life Safety, 16, 186-190 [in Ukrainian].

10. Arkorful, V., \& Abaidoo, N. (2015). The role of e-learning, advantages and disadvantages of its adoption in higher education. Int. J. Educ. Res., 12, 29-42.

11. Baqir, S.M., \& Mustansir, F. (2021). Online medical education and examinations during COVID-19: perspectives of a teaching associate. J. Coll. Physicians Surg. Pak., 31, 16-18. DOI https://doi.org/10.29271/jcpsp.2021.01.S16.7.

Received 13.09.21

Recommended 20.09.21 